\title{
Molecular Identification of Triticale Introgression Lines Carrying Leaf Rust Resistance Genes Transferred From Aegilops Kotschyi Boiss. and Ae. Tauschii Coss.
}

\author{
Michał Kwiatek ( $\square$ michal.kwiatek@up.poznan.pl) \\ Instytut Genetyki Roslin Polskiej Akademii Nauk https://orcid.org/0000-0001-9442-3124 \\ Jolanta Belter \\ Instytut Genetyki Roslin Polskiej Akademii Nauk \\ Waldemar Ulaszewski \\ Instytut Genetyki Roslin Polskiej Akademii Nauk \\ Roksana Skowrońska \\ Poznan University of Life Sciences: Uniwersytet Przyrodniczy w Poznaniu

\section{Aleksandra Noweiska} \\ Poznan University of Life Sciences: Uniwersytet Przyrodniczy w Poznaniu \\ Halina Wiśniewska \\ Instytut Genetyki Roslin Polskiej Akademii Nauk
}

\section{Research Article}

Keywords: Aegilops, genomic in situ hybridization, leaf rust, molecular markers, resistance genes, triticale

Posted Date: February 18th, 2021

DOl: https://doi.org/10.21203/rs.3.rs-204431/v1

License: (c) (i) This work is licensed under a Creative Commons Attribution 4.0 International License. Read Full License 


\section{Abstract}

Triticale ( $\times$ Triticosecale Wittmack) is a commercial hybrid harboring wheat (Triticum sp.) and rye (Secale cereale L.) genomes. The limited genetic diversity of this crop resulted in the collapse of fungal disease resistance. Leaf rust disease, caused by Puccinia triticina Eriks. is reported to reduce the triticale yield significantly (more than $30 \%$ ). There is a need to enlarge the genetic variability of this crop including leaf resistance genes. The main aim of this research was to transfer $L r 39$ and $L r 54$ leaf rust resistance genes into triticale from Aegilops tauschii and Ae. kotschyi, respectively. A reaction of seedlings of 200 plants of two triticale-Aegilops translocation lines (Bogo$2 D^{t} .2 R$ and Sekundo-2 $S^{k} .2 R$ ) was compared after inoculation with a natural mixture of $P$. triticina races, specific to triticale. Before inoculation, each plant was screened using molecular cytogenetics and molecular markers linked to leaf rust resistance genes. Presence of Aegilops chromosome segments was confirmed using genomic in situ hybridization (GISH). Lr39 and Lr54 leaf rust resistance genes were identified using Xgdm35 and S14 molecular markers, respectively. After inoculation, a significant improvement of resistance severity was observed in Sekundo$2 S^{k} .2 R$ in comparison with triticale cv. Sekundo plants. The resistance level of Bogo-2 $D^{t} .2 R$ did not differ compared to triticale $\mathrm{cv}$. Bogo plants. It was shown, that $L r 39$ gene did not increase the leaf rust resistance level of triticale cv. Bogo.

\section{Introduction}

Triticale ( $\times$ Triticosecale Wittmack $2 n=6 x=42$ chromosomes, AABBRR) is a hybrid crop composed of wheat (Triticum sp.) and rye (Secale cereale L.) genomes, which is commercially used for forage, food and biofuel production (Meale and Mcallister 2015). Leaf rust, caused by fungus Puccinia triticina Eriks, is one of the most destructive foliar diseases of triticale worldwide. This disease occurs mainly on the leaf blade, producing small elliptical orange-red pustules on the upper surface and causing premature defoliation. It causes both yield losses and downgrading in quality (Hanzalová and Bartoš, 2011) and its natural populations virulence is higher on triticale in comparison to wheat (Mikhailova et al., 2009). During the evolution, plants have elaborated large number of resistant genes (R genes) as a part of their defense system. $\mathrm{R}$ genes encode receptors, recognizing, produced by pathogen, avirulence gene-dependent elicitors (De Wit, 1997). In turn, triticale suffers lack of the evolution process. The genetic pool of wheat and rye forms for cross-hybridizations were relatively narrow and it had and significant effect on low genetic variability of this crop (Kwiatek and Nawracała, 2018). This is the most possible reason of the resistance collapse of triticale in last two decades (Arseniuk and Góral, 2015).

The most economical and environmentally friendly approach to reduce yield losses, caused by leaf rust diseases, is the host plant genetic resistance. This kind of resistance is crucial for farming with no use or limited pesticides. Cultivars of wheat with improved disease resistance have been successfully developed, using $L r$ genes, in breeding programs. Proteins encoded by some $L r$ genes have evolutionary conserved DNA motifs such as nucleotide binding site (NBS) and leucine repeat rich (LRR) (Kolmer, 2013). More than 80 genes for resistance to leaf rust have already been catalogued on wheat and its relatives (Mclntosh et al., 2019).

The Aegilops genus is the closest wild relative of Triticum which includes cultivated forms of wheat. Several Aegilops accessions have resistance to fungal pathogens of cereals. New gene variants derived from Aegilops species, which are related to biotic stress resistance are considered as sources for improving the stress tolerance of wheat and triticale (Schneider et al. 2008; Kwiatek \& Nawracała, 2018). What is more, the polyploid nature of the wheat or triticale genome facilitates the survival of genetically unbalanced genomic material within the nucleus. 
This enables the introduction of alien DNA into the wheat/triticale genome since even the addition of whole chromosome arms from a different genome may be tolerated (Kwiatek and Nawracała, 2018).

The first alien $L r$ gene, that has ever been introduced into wheat genome was $L r 9$. This gene was transferred by Sears (1956) from Ae. umbellulata into hexaploid wheat through X irradiation induced translocation. A number of other leaf rust resistance genes were transferred from progenitor or related non-pogenitor Aegilops species and commercially utilized in wheat (Schneider et al., 2008). Aegilops tauschii Coss, the D-genome donor of wheat, has been a rich source of leaf rust resistance genes (Rayburn and Gill, 1987). Several leaf rust resistance genes ( $L r 22 a$ (2D), Lr32 (3D), Lr39 (2D) have been transferred into triticale from Ae. tauschii (Kwiatek et al., 2015; Majka et al. 2018).

Homoeologus pairing and recombination has been widely used to transfer valuable resistance genes from alien chromosome to wheat chromosome. Chromosome translocations of leaf rust resistance gene are said to occure spontaneously when wheat-Aegilops introgression lines are backcrossed (Faris and Gill, 2002). One of the most efficient techniques of introducing alien chromatin into wheat or triticale is recombination-based chromosome engineering (Kwiatek and Nawracała 2018). Marais et al (2005) have introduced, Ae. kotschyi derived, leaf and stripe rust resistant genes $L r 54$ and $Y r 37$, respectively, to the genome of wheat. Double monosomic for 2D chromosome of wheat and a $2 \mathrm{~S}^{\mathrm{k}}$ chromosome of Ae. kotschyi were used in this study. A translocation that was formed following centric breaking and subsequent fusion of an Ae. kotschyi chromosome $2 S^{k} L$ arm with 2DS arm of wheat. Ulaszewski et al. (2019) produced Robertsonian translocations (RobTs) in the progeny of triticale cv. Sekundo plants with monosomic substitution of Ae. kotschyi chromosome $2 S^{k}(2 R) .2 S^{k} .2 R$ compensatory RobTs were produced using utilized ditelosomic lines of triticale carrying 2RS (short arm) and 2RL (long arm) telosomic chromosomes. The authors reported that six plants carried T2RS.2Sk ${ }^{k}$ translocation. Moreover, Kwiatek (2018) used the same strategy and developed five plants carrying $2 D^{t} .2 R$ compensatory RobTs (introduced from Ae. tauschii into cv. Bogo).

Neither the mechanisms nor the expression of $L r 39$ and $L r 54$ genes responsible for the leaf rust resistance have been sufficiently studied in Aegilops - triticale translocation lines. Hence, the aim of this work was to evaluate the resistance of the offspring of translocation lines of triticale with chromatin of Ae.tauschii and Ae. kotschyi at seedling stage for infection of natural mixture of Puccinia triticina Eriks in controlled condition.

\section{Materials And Methods}

\section{Plant material}

An offspring of two triticale lines carrying two compensated chromosome translocations (2D ${ }^{t} .2 R$ and $\left.2 S^{k} .2 R\right)$ (Table 1). Alien chromatin segments were introduced into triticale cultivars: Bogo and Sekundo from Ae. tauschii and Ae. kotschyi, respectively (Kwiatek et al. 2018; Ulaszewski et al. 2019). Offspring plants of triticale translocation lines were used for marker assisted selection of plants carrying Lr39 and Lr54 leaf rust resistances genes. Selected plants were called Bogo-2 $D^{t} .2 R$ and Sekundo-2S ${ }^{k} .2 R$; and evaluated for leaf rust symptoms. Additionally, each experiment involved two negative controls. First control included 30 plants of each of three triticale cultivars (Bogo, Sekundo), which were used in order to compare the infection response of translocation plants. The second control involved 30 plants of bread wheat cv. Michigan Amber, which is reported to be highly susceptible to leaf rust infection (Kolmer et al., 2013). Moreover, 30 plants of KS90WGRC10 wheat line, which was reported to carry Lr39 
loci derived from Ae. tauschii TA1675 (Raupp et al. 2001), were used as positive control to check the virulence of a natural mixture of leaf rust urediniospores on Lr39 gene.

Table 1

Cytogenetic characterization of the introgression line of triticale carrying chromatin fragments with leaf rust resistance genes Lr39 and Lr54 transferred from Aegilops kotschyi and Ae tauschii into triticale cv. Bogo and Sekundo, respectively.

\begin{tabular}{|c|c|c|c|c|c|}
\hline \multirow{2}{*}{$\begin{array}{l}\text { Translocation } \\
\text { lines of triticale } \\
\text { (type of } \\
\text { chromosome } \\
\text { translocation) }\end{array}$} & \multirow{2}{*}{$\begin{array}{l}\text { Number of } \\
\text { offspring } \\
\text { plants }\end{array}$} & \multirow{2}{*}{$\begin{array}{l}\text { Transferred leaf rust } \\
\text { resistance genes } \\
\text { (chromosome localization) }\end{array}$} & \multirow{2}{*}{$\begin{array}{l}\text { Donor of } \\
\text { alien } \\
\text { chromatin }\end{array}$} & \multicolumn{2}{|c|}{$\begin{array}{l}\text { Number of plants offspring } \\
\text { carrying }\end{array}$} \\
\hline & & & & $\begin{array}{l}\text { Chromosome } \\
\text { translocations }\end{array}$ & $\begin{array}{l}\text { Chromosome } \\
\text { substitution }\end{array}$ \\
\hline $\begin{array}{l}\text { Bogo-2D } \mathrm{D}^{\mathrm{t}} \cdot 2 \mathrm{R} \\
\text { (RobTs 2D } .2 \mathrm{R})\end{array}$ & 100 & $\operatorname{Lr39}\left(2 \mathrm{D}^{\mathrm{t}}\right)$ & $\begin{array}{l}\text { Ae. } \\
\text { tauschii }\end{array}$ & $\begin{array}{l}100 \\
(2 D S .2 R S-2 R L \\
\text { and 2RS.2DS- } \\
\text { 2DL) }\end{array}$ & 0 \\
\hline $\begin{array}{l}\text { Sekundo- } \\
2 S^{k} .2 R \\
\text { (RobTs 2Sk.2R) }\end{array}$ & 100 & $\operatorname{Lr} 54\left(2 \mathrm{~S}^{\mathrm{k}}\right)$ & $\begin{array}{l}\text { Ae. } \\
\text { kotschyi }\end{array}$ & $\begin{array}{l}18 \\
\left(2 S^{k} S .2 R S-2 R L\right. \\
\text { and } 2 R S .2 S^{k} S- \\
\left.2 S^{k} L\right)\end{array}$ & $\begin{array}{l}82 \\
\left(2 S^{k} / 2 R\right)\end{array}$ \\
\hline
\end{tabular}

\section{SSR Marker Screening}

Genomic DNA of three Aegilops accessions, three donor triticale cultivars and 300 plants with alien translocations (3 combinations $\times 100$ plants), were isolated using Plant DNA Purification Kit (EurX Ltd., Gdańsk, Poland). All primers (Table 3) were manufactured by Sigma-Aldrich (Merck). PCR reactions were performed in a LabCycler thermal cycler (SensoQuest Biomedizinische Elektronik, Goettingen, Germany). The $20 \mu \mathrm{L}$ PCR reaction consisted of $150 \mathrm{nM}$ each primer, $0.2 \mathrm{mM}$ of each nucleotide, $1.5 \mathrm{mM} \mathrm{MgCl}_{2}, 0.2$ units of Taq-DNA hot-start polymerase (TaqNovaHS, Blirt, Poland), and 50 ng of genomic DNA as a template. A typical PCR procedure was as follows: 5 min at $95^{\circ} \mathrm{C}$, then 35 cycles of $30 \mathrm{~s}$ at $94^{\circ} \mathrm{C}, 30 \mathrm{~s}$ at $50-60^{\circ} \mathrm{C}$ (depending on the primer, Table 2 ), $1 \mathrm{~min}$ at $72^{\circ} \mathrm{C}$, and 5 min at $72^{\circ} \mathrm{C}$. $0.5 \mu \mathrm{L}$ Midori Green Direct (Nippon Genetics Europe) was added to each amplification product, ran on $2 \%$ agarose gel (Sigma), and then visualized and documented using EZ GelDoc System (BioRad). Each sample was tested twice. Third, additional run was made in case of discrepancy in the results. 
Table 2

Means of infection levels scored 5, 10 and 15 days post inoculation (dpi).

\begin{tabular}{|llllll|}
\hline Plant material & Number of plants tested & \multicolumn{4}{l|}{ Means of infection levels } \\
\cline { 3 - 6 } & & $\mathbf{5} \mathbf{~ d p i}$ & $\mathbf{1 0} \mathbf{~ d p i}$ & $\mathbf{1 5} \mathbf{d p i}$ & mean \\
\hline Bogo-Lr39 (introgression line) & 100 & 3.94 & 4.13 & 4.2 & 4.09 \\
\hline Sekudo-Lr54 (introgression line) & 100 & 1.59 & 1.65 & 1.67 & 1.64 \\
\hline Triticale cv. Bogo (donor control) & 30 & 4.0 & 4.1 & 4.1 & 4.07 \\
\hline Triticale cv. Sekundo (donor control) & 30 & 7.0 & 7.1 & 7.4 & 7.17 \\
\hline KS9OWGRC10 (wheat control; Lr39) & 30 & 3.9 & 4.2 & 4.3 & 4.13 \\
\hline Michigan Amber (wheat control) & 30 & 8.6 & 8.9 & 8.9 & 8.8 \\
\hline
\end{tabular}

Table 3

Primer sequences and PCR conditions used for markers identification of Lr39 and Lr54 genes

\begin{tabular}{|c|c|c|c|c|c|c|}
\hline $\begin{array}{l}\text { Molecular } \\
\text { marker }\end{array}$ & $\begin{array}{l}\text { Leaf } \\
\text { resistance } \\
\text { gene }\end{array}$ & Primer sequences ( $5^{\prime}$ to $\left.3^{\prime}\right)$ & $\begin{array}{l}\text { Amplification } \\
\text { temperature } \\
\left({ }^{\circ} \mathrm{C}\right)\end{array}$ & $\begin{array}{l}\text { Fragment } \\
\text { size (bp) } \\
\text { in } \\
\text { Aegilops }\end{array}$ & $\begin{array}{l}\text { Fragment } \\
\text { size in } \\
\text { triticale }\end{array}$ & Source \\
\hline \multirow[t]{2}{*}{ Xgdm35 } & \multirow[t]{2}{*}{ Lr39 } & СCTGCTCTGCCCTAGATACG & \multirow[t]{2}{*}{$55^{\circ} \mathrm{C}$} & \multirow[t]{2}{*}{190} & \multirow[t]{2}{*}{ null } & \multirow{2}{*}{$\begin{array}{l}\text { Pestsova } \\
\text { et al. } \\
2000\end{array}$} \\
\hline & & ATGTGAATGTGATGCATGCA & & & & \\
\hline \multirow[t]{2}{*}{$S 14-297$} & \multirow[t]{2}{*}{ Lr54 } & CATGCAGAAAACGACACACC & \multirow[t]{2}{*}{$60^{\circ} \mathrm{C}$} & \multirow[t]{2}{*}{410} & \multirow[t]{2}{*}{ null } & \multirow{2}{*}{$\begin{array}{l}\text { Smit } \\
2013\end{array}$} \\
\hline & & GGTAAGTGGTCAGGCGTTGT & & & & \\
\hline
\end{tabular}

\section{Genomic in situ hybridization}

Chromosome spreads of 200 plants were prepared using enzymatic digestion and squashing protocol described by Kwiatek et al. (Kwiatek et al., 2017). Molecular probes for alien chromatin identification were prepared using total genomic DNA of Ae. sharonensis and Ae tauschii, which were purified using GeneMATRIX Plant \& Fungi DNA Purification Kit (EURx, Gdansk, Poland). Ae. sharonensis is reported as a donor of $S^{k}$-genome of Ae. kotschyi (Ruban and Badaeva, 2018). Genomic DNA of alien species was labeled by nick translation with Digoxigenin-11-dUTP dye (Merck). Genomic in situ hybridization (GISH) was carried out according to previously published protocols (Kwiatek et al., 2016). Chromosome spreads were examined with the Olympus BX 61 automatic epifluorescence microscope equipped with Olympus XM10 CCD camera. Olympus Cell-F (version 3.1; Olympus Soft Imaging Solutions GmbH: Münster, Düsseldorf, Germany) imaging software and PaintShop Pro X5 software (version 15.0.0.183; Corel Corporation, Ottawa, ON, Canada) was used for image processing and documentation.

\section{Evaluation of leaf rust symptoms in growth chamber}

Evaluation of leaf rust was carried out in in growth chamber (at IPG PAS) using a natural mixture of leaf rust urediniospores, which were collected from triticale fields in three localizations in Wielkopolska region: IPG PAS

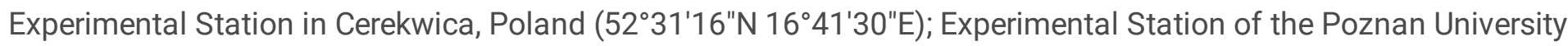
of Life Sciences (PULS), Dłoń, Poland (51 $\left.{ }^{\circ} 41^{\prime} 22^{\prime \prime} \mathrm{N} 17^{\circ} 04^{\prime} 23^{\prime \prime E}\right)$; and Experimental Garden of the Department of Genetics and Plant Breeding (PULS) in Poznań (52 $\left.25^{\prime} 26^{\prime \prime} \mathrm{N} 16^{\circ} 54^{\prime} 07^{\prime \prime} \mathrm{E}\right)$. Plants at three-leaf stage were challenged with leaf rust by spraying urediniospore solution containing $0.1 \%$ Tween 20 . The inoculated plants were then 
incubated in a humid growth chamber free from light for 15 days. After inoculation, the plants were maintained under a day/night photoperiod of $18 / 6 \mathrm{~h}$, a temperature of $16-22^{\circ} \mathrm{C}$. Winter triticale cv. Bogo and Sekundo, winter wheat cv. Michigan Amber were taken as the susceptible controls. KS90WGRC10 wheat line was used as a positive control for $L r 39$ gene. The infection type of each individual was scored at three timepoints (5, 10 and 15 days post inoculation - dpi) using an infection scale adapted from (Roelfs, 1988) and transformed into nine-grade scale (1 high resistance, 9 - susceptibility, Table 2; McNeal et al 1971). The means of scores of leaf rust symptoms were compared between translocation lines and controls including acceptor cultivars of triticale and Michigan Amber wheat using analysis of variance (ANOVA) and Tukey's highest significant difference (HSD) test (Supporting Information 1, 2 and 3).

\section{Results}

\section{Marker assisted selection}

In the first step marker assisted selection was used to choose two hundred plants from the progeny of each of two Aegilops-triticale translocation lines carrying Lr39 or Lr54 genes. Each sample was tested twice. 100 offspring plants of $2 D^{t} .2 R$ triticale translocation line (an introgression of Ae. tauschii chromatin) showed a 190 bp product afer PCR reaction with $X g d m 35$ marker linked to $L$ r39 resistance gene (Fig. 1a). The same product was observed for Ae. tauschii control. No amplification product was observed for triticale cv. "Bogo. 100 plants with Lr54 gene loci were selected from the recombinants derived from $2 S^{k} .2 \mathrm{R}$ triticale translocation line (an introgression of $A e$. kotschyi chromatin) by the use of $S 14$ marker. A 300 bp amplification product was observed for Ae. kotschyi control and hybrid plants (Fig. 1b). Lack of amplification products was characteristic for triticale cv. "Sekundo". Both groups of plants were evaluated for the evaluation of infection in the further steps of the experiment.

\section{Genomic in situ hybridization}

In total, 200 selected plants were used for genomic in situ hybridization experiment. This approach aimed in the evaluation of the amount of alien chromatin segments in triticale genetic background (Table 1). Within the first group (100 plants), two types of chromosome translocations including large segment of $2 \mathrm{D}^{\mathrm{t}}$ chromosome with the centromere region and short distal chromosome translocations were observed (Fig. 2a). The chromosomes sets of 100 plants belonging to second group were more diversified. 18 plants showed a two different types of chromosome translocations, including large parts of $2 \mathrm{~S}^{\mathrm{k}}$ chromosome with the centromere region or short segments of this chromosome located distally in the subtelomeric region of 2R chromosomes (Fig. 2b). 82 plants showed complete $2 S^{k}$ chromosomes (Fig. 2c).

\section{Evaluation of leaf rust symptoms}

The phenotypes of 200 plants belonging to two combinations (100 plants each) of triticale translocation lines was evaluated at the seedling stage in the growth chamber and compared to phenotypes of acceptor cultivars of triticale (Bogo and Sekundo), Michigan Amber wheat and KS90WGRC10 wheat line (30 plants each) (Table 2). The mean score for Michigan Amber plants (8.8) showed, that the inoculation solution was effective for induction of the infection. The comparison of the means of infection levels, which were calculated for triticale cultivars (donors) showed that cv. Bogo represented a higher resistance level (4.07) compared to cv. Sekundo (7.17 at HSD $0.01=0.43)$ (Table 2; Supporting Information 1). The mean score of three independent evaluations of infection level $(5,10$ and 
$15 \mathrm{dpi}$ ) in Bogo-2 $\mathrm{D}^{\mathrm{t}}$.2R plants varied between 3.94 and 4.2 (Table 2). The results were comparable with the mean sore of infection of triticale cv. Bogo (4.07) and KS90WGRC10 (4.13), which is reported to carry Lr39 gene (Table 2). The difference between scores collected 5 days post infection were significantly lower (at $P=0.01$ level) when compared to scores screened after 15 days post infection (Supporting Information 2). The second group of Sekundo-2Sk.2R plants showed a seedling resistance. The infection rate was 1.59; 1.65 and 1.67 (5, 10 and 15 dpi) (Table 2) and did not differ significantly considering the evaluation timepoints (Supplementary table 3). In comparison, plants of cv. Sekundo showed limited resistance (7.17). The Tukey HSD test revealed that the differences in infection scores between Sekundo-2S ${ }^{k} .2 \mathrm{R}$ and cv. Sekundo plants were significant at $a=0.01$ level $\left(\mathrm{HSD}_{0.01}=0.36\right)$.

\section{Discussion}

The main aim of this research was to evaluate the effectiveness of $L r 39$ and $L r 54$ leaf rust resistance genes, which were transferred separately into two triticale cultivars (Bogo and Sekundo) through development of the $2 A e .2 \mathrm{R}$ compensating chromosome translocation lines. Desirable genes in hybrids of crop plants and wild relatives are inherited alongside with potentially unwanted genes on the alien chromosome or chromosome segment. In order to reduce the size of the whole arm translocations $\left(2 \mathrm{D}^{\mathrm{t}} .2 \mathrm{R}\right.$ and $\left.2 \mathrm{~S}^{\mathrm{k}} .2 \mathrm{R}\right)$ and overcome the linkage drag, homoeologous pairing was induced between the triticale and corresponding Ae. tauschii and Aegilops kotschyi chromatin. Genomic in situ hybridization supported by the screening of molecular markers linked to leaf rust resistance genes allowed to select plants for inoculation tests. Cytogenetic analyses showed that $2 \mathrm{D}^{\mathrm{t}}$.2R Robertsonian translocations (RobTs) have been rearranged. All 100 Bogo-2 $D^{t}$.2R plants showed different locations of chromosome breakpoints (Fig. 2a) compared to compensating Robertsonian translocations, which were reported in the parental forms (Ulaszewski et al. 2019; Kwiatek et al. 2018). Induced reduction of introgressed whole arms of alien chromosomes was reported multiple times (Howell et al., 2014; Lukaszewski, 2000; 2010). In these studies 1RS.1BL and 1BS.1RL Robertsonian translocations were produced by centric misdivision of univalents. The reduction of alien segments was induced by crossing with $p h 1 b$ wheat mutants, which resulted in production of a series of homoeologous recombinants 1BS1RS (Lukaszewski 2000). In our study plants with RobTs were self-pollinated. It could be possible, that 2D ${ }^{t} S .2 R$ and $2 R S .2 D^{t} L$ chromosomes paired and recombined and novel configurations of those two chromosomes appeared in the offspring (Fig. 2a). Considering the homoeology along $2 \mathrm{D}^{t} S .2 \mathrm{R}$ and $2 \mathrm{RS} .2 \mathrm{D}^{\mathrm{t}} \mathrm{L}$ chromosomes, only centromere regions might be supposed to be responsible for pairing during meiosis. It was reported that centromere structure of 1BS.1RL centric translocations is hybrid (Wang et al., 2017). Wang et al (2017) observed that wheat-derived CENH3 bound to both the wheat and rye centromeres in the 1RS.1BL translocation chromosomes. It was also showed that a rye centromere-specific retrotransposon was actively transcribed in 1RS.1BL translocations (Wang et al. 2017). Lukaszewski (2010) showed that chromosome fragments consisting of only the centromere region did not survive to the next generation, whereas acrocentric chromosomes composed of the centromeres and parts of the pericentric chromatin did survive, which could be interpreted that the pericentric chromatin provides sister chromatid cohesion. Structural rearrangements of compensating $2 S^{k} .2 R$ centric translocations were observed in Sekundo- $2 S^{k} .2 R$ plants, however this was characteristic only for $18 \%$ of plants. Majority of Sekundo-2 $S^{k} .2 R$ plants (82\%) revealed rejoined of $2 S^{k}$ chromosome, which was puzzling (Fig. $2 \mathrm{c}$ ). It could be possible, that compensating $2 S^{k}$. $2 \mathrm{R}$ Robertsonian translocations were broken and the meiotic cells with separated $2 S^{k}$ chromosome arms that have rejoined into $2 S^{k}$ and $2 \mathrm{R}$ chromosomes were functional. This assumption can be linked with the preferential transmission (Endo, 2007) of $2 S^{k}$ chromosome in wheat and triticale (Kwiatek et al., 2017) background, which is caused by gametocidal action. 
Two selected groups of triticale translocation plants carried Lr39 or Lr54 leaf rust resistance genes. Both groups of plants were tested using a mixture of $P$. triticina races, which naturally occurred on the triticale plantations in Wielkopolska regions. Application of the natural mixture of the $P$. triticina pathotypes is the best way to evaluate the overall leaf rust resistance level and the usability of translocation plants of triticale for breeding purposes, as well. It is reported, that triticale is infected by the races specific to both: wheat and rye, however it was noticed that triticale is more easily attacked by the wheat physiological forms of the rusts than by the rye ones (Arseniuk, 1996). It is also known that the rust species can hybridize through spontaneous crossings, e.g. $P$. graminis f. sp. trifiei and $P$. graminis $\mathrm{f}$. sp. secalis on Berberis vulgaris, as well as somatically on graminaceous hosts observed in Sekundo$2 \mathrm{~S}^{\mathrm{k}} .2 \mathrm{R}$ in comparison with triticale $\mathrm{cv}$. Sekundo plants. The mean level of resistance was very high $(1.59 ; 1.65$ and 1.67 after 5,10 and 15 days after infection, respectively). Such low infection rate can be considered as a result of Lr54 gene expression. In similar study, Marais et al. (2005) developed a 2DS.2Sk L wheat-Ae.kotschyi line (called S14 translocation) derived from the test cross of double monosomic 2D/Ae. kotschyi group2//_CS_-S) contained 96\% resistant plants (72 tested) which were tested for resistance to eight Pt pathotypes (UVPrt2, UVPrt3, UVPrt4, UVPrt5, UVPrt8, UVPrt9, UVPrt10 and UVPrt13) and two Pst pathotypes (6E16A- and 6E22A-) endemic to South Africa. Moreover, it was reported that the S14 translocation evidently had preferential transmission (Marais et al. 2005). The results of inoculation test were similar to present study of $2 \mathrm{R} .2 \mathrm{~S}^{\mathrm{k}}$ translocation lines.

In comparison, the leaf rust resistance level did not differ between plants of Bogo-2 $\mathrm{D}^{t} .2 \mathrm{R}$ line and triticale cv. Bogo. What is more, the infection types were similar to those, scored on plants of KS90WGRC10 wheat line, which is reported to carry a Lr39 leaf rust gene (Raupp et al. 2001; Gill et al., 2008) The parental forms for development Bogo-2 $D^{t} .2 R$ translocation line were selected from the monosomic $2 D^{t}$ addition triticale genotypes carrying $L r 39$ locus (Kwiatek et al., 2015; Majka et al. 2018). The leaf rust resistance of these genotypes was then determined at the macroscopic and microscopic level at the seedling (Majka et al., 2018). A board spectrum of $P$. triticiana was used including isolates virulent to $L r 39$. The results showed, that hybrid plants revealed a limited level of leaf rust resistance at the seedling stage (Majka et al. 2018). The infection rate of Bogo-2 $\mathrm{D}^{\mathrm{t}}$.2R plants was comparable with results of inoculation performed on plants of triticale cv. Bogo. Majka et al (2018) tested this cultivar, as well as monosomic addition (M2Dt) lines of cv. Bogo, using a board spectrum of pure leaf rust isolates, which showed diverse response of Thatcher NILs containing Lr39 gene (including complete and limited virulence). It was reported, that triticale cv. Bogo is already very resistant and the introgression of complete $2 \mathrm{D}^{\mathrm{t}}$ chromosome with $L \mathrm{r} 39 \mathrm{gene}$ showed no additional effect (Majka et al. 2018), which is a similar to the results obtained in present study of Bogo$2 \mathrm{D}^{\mathrm{t}} .2 \mathrm{R}$ translocation plants.

In summary, it could be said that only $L r 54$ gene provided a significant improvement of the leaf rust resistance of triticale cv. Sekundo. These genetic stocks seem to be promising plant materials in the context of triticale resistance breeding. However, further investigation aiming in the evaluation of the linkage drag effect on the yield, plant morphology and quality traits is required.

\section{Declarations}

\section{Compliance with Ethical Standards}

\section{Funding}

This research and the APC were funded by NATIONAL CENTRE FOR RESEARCH AND DEVELOPMENT, Poland (Narodowe Centrum Badań i Rozwoju, Polska), grant number LIDER/3/0004/L-8/16/NCBR/2017. 


\section{Conflict of interest}

The authors declare that they have no conflict of interest.

\section{Ethics approval}

Not applicable.

\section{Availability of data and material}

The data that support the findings of this study are available from the corresponding author upon reasonable request.

\section{Code availability}

Not applicable.

\section{Authors' contributions}

MK, JB, WU, RS and AN made the experiments and analyses, MK wrote the first draft and incorporated all inputs from co-authors. MK initiated the project. HW revised the draft and made suggestions for improving the manuscript.

\section{Acknowledgements}

The authors would like to acknowledge and thank Dr. Harrold Bockelman at the USDA/ARS Small Grains Laboratory, Aberdeen (ID, USA) for providing the seeds of KC90WGRC10 wheat accession. In addition, we would like to thank all of the reviewers and manuscript editor for their careful review of the manuscript and for their excellent suggestions for improving our initial work. The research was conducted in the absence of any commercial or financial relationships that could be construed as a potential conflict of interest.

\section{References}

1. Arseniuk, E. (1996) Triticale Diseases - a Review, in: Triticale: Today and Tomorrow. pp. 499-525. https://doi.org/10.1007/978-94-009-0329-6_65

2. Arseniuk, E., Góral, T. (2015) Triticale Biotic Stresses--Known and Novel Foes, in: Eudes, F. (Ed.), Triticale. Springer International Publishing, Cham, pp. 83-108. https://doi.org/10.1007/978-3-319-22551-7_5

3. Baron, V., Juskiw, P., Aljarrah, M. (2015) Triticale as a Forage. pp. 189-212. https://doi.org/10.1007/978-3-31922551-7_10

4. De Wit, P.J.G.M. (1997) Pathogen avirulence and plant resistance: a key role for recognition. Trends Plant Sciences, 2, 452-458. https://doi.org/https://doi.org/10.1016/S1360-1385(97)01139-4

5. Endo, T.R. (2007) The gametocidal chromosome as a tool for chromosome manipulation in wheat. Chromosome Research, 15, 67-75. https://doi.org/10.1007/s10577-006-1100-3

6. Faris, J.D., Gill, B.F. and B.S. (2002) Wheat Genomics: Exploring the Polyploid Model. Current Genomics. https://doi.org/http://dx.doi.org/10.2174/1389202023350219

7. Gill, B.S., Huang, L., Kuraparthy, V., Raupp, W.J., Wilson, D.L., Friebe, B. (2008) Alien genetic resources for wheat leaf rust resistance, cytogenetic transfer, and molecular analysis. Australian Journal of Agricultural Research, 
59, 197-205.

8. Hanzalová, A., Bartoš, P. (2011) Resistance of Triticale to Wheat Leaf Rust (Puccinia triticina), Czech Journal of Genetics and Plant Breeding, 47, 10-16. https://doi.org/10.17221/100/2010-CJGPB

9. Huerta-Espino, J., Singh, R.P., Germán, S., McCallum, B.D., Park, R.F., Chen, W.Q., Bhardwaj, S.C., Goyeau, H. (2011) Global status of wheat leaf rust caused by Puccinia triticina. Euphytica, 179, 143-160. https://doi.org/10.1007/s10681-011-0361-x

10. Howell, T., Hale, I., Jankuloski, L., Bonafede, M., Gilbert, M., Dubcovsky, J. (2014) Mapping a region within the 1RS.1BL translocation in common wheat affecting grain yield and canopy water status. Theoretical and Applied Genetics, 127, 2695-2709. https://doi.org/10.1007/s00122-014-2408-6

11. Kolmer, J.A., Hanzalova, A., Goyeau, H., Bayles, R., Morgounov, A. (2013) Genetic differentiation of the wheat leaf rust fungus Puccinia triticina in Europe. Plant Pathology, 62, 21-31. https://doi.org/10.1111/j.13653059.2012.02626.x

12. Kwiatek, M., Belter, J., Majka, M., Wiśniewska, H. (2016) Allocation of the S-genome chromosomes of Aegilops variabilis carrying powdery mildew resistance in triticale (× Triticosecale Wittmack). Protoplasma 253. (2):32943. doi: 10.1007/s00709-015-0813-6.

13. Kwiatek, M., Majka, M., Wiśniewska, H., Apolinarska, B., Belter, J. (2015) Effective transfer of chromosomes carrying leaf rust resistance genes from Aegilops tauschii into hexaploid triticale (X Triticosecale Witt.) using Ae. tauschii $\times$ Secale cereale amphiploid forms. Journal of Applied Genetics, 56, 163-168. https://doi.org/10.1007/s13353-014-0264-3

14. Kwiatek, M.T. (2018) Transfer of chromatin of wild goatgrasses (Aegilops) carrying genes responsible for resistance to leaf rust into triticale ( $\times$ Triticosecale Wittmack) using chromosome engineering, in: Book of Abstracts, EMBO 6th International Meeting Plant Genome Stability \& Change, June, 3-6, 2018, IPK Gatersleben, Germany. Gatersleben, p. p.28.

15. Kwiatek, M.T., Nawracała, J. (2018) Chromosome manipulations for progress of triticale ( $\times$ Triticosecale) breeding. Plant Breeding, 137, 823-831. https://doi.org/10.1111/pbr.12652

16. Kwiatek, M.T., Wiśniewska, H., Ślusarkiewicz-Jarzina, A., Majka, J., Majka, M., Belter, J., Pudelska, H. (2017) Gametocidal Factor Transferred from Aegilops geniculata Roth Can Be Adapted for Large-Scale Chromosome Manipulations in Cereals. Frontiers in Plant Sciences 8, 409. https://doi.org/10.3389/fpls.2017.00409

17. Luig, N.H., Watson, I.A. (1972) The Role of Wild and Cultivated Grasses in the Hybridization of Formae Speciales of Puccinia Graminis. Australian Journal of Biological Sciences, 25, 335-342.

18. Lukaszewski, A.J. (2010) Behavior of Centromeres in Univalents and Centric Misdivision in Wheat. Cytogenetic and Genome Research, 129, 97-109. https://doi.org/10.1159/000314108

19. Lukaszewski, A.J. (2000) Manipulation of the 1RS.1BL Translocation in Wheat by Induced Homoeologous Recombination. Crop Science, 40, 216-225.

20. Majka, M., Serfling, A., Czembor, P., Ślusarkiewicz-Jarzina, A., Kwiatek, M.T., Ordon, F., Wiśniewska, H. (2018) Resistance of (Aegilops tauschii $\times$ Secale cereale) $\times$ Triticosecale Hybrids to Leaf Rust (Puccinia triticina) Determined on the Macroscopic and Microscopic Level. Frontiers in Plant Sciences, 9:1418. doi: 10.3389/fpls.2018.01418

21. Marais, G.F., McCallum, B., Marais, A.S. (2005) Leaf rust and stripe rust resistance genes Lr54 and Yr37 transferred to wheat from Aegilops kotschyi. Plant Breeding, 124, 538-541. https://doi.org/10.1007/s10681006-9092-9 
22. McIntosh, R.., Dubcovsky, J., Rogers, W.J., Morris, C., Xia, X.C. (2019). Catalogue of Gene Symbols for Wheat [WWW Document]. URL https://shigen.nig.ac.jp/wheat/komugi/genes/symbolClassList.jsp

23. McNeal, F.H., Konzak, C.F., Smith, E.P., Tate, W.S., and Russell, T.S. (1971) A uniform system for recording and processing cereal research data. US Dept. Agric. Res. Serv. ARS 34, 121-43.

24. Meale, S., Mcallister, T. (2015) Grain for Feed and Energy. pp. 167-187. https://doi.org/10.1007/978-3-31922551-7_9

25. Mikhailova, L.A., Merezhko, A.F., Funtikova, E.Y. (2009) Triticale diversity in leaf rust resistance. Russ. Agric. Sci. 35, 320. https://doi.org/10.3103/S1068367409050097

26. Pestsova, E.; Ganal, M.W.; Röder, M.S. (2000) Isolation and mapping of microsatellite markers specific for the D genome of bread wheat. Genome, 43(4), 689-697.

27. Raupp, W.J., Sukhwinder_Singh, Brown-Guedira, G.L, Gill, B.S. (2001) Cytogenetic and molecular mapping of the leaf rust resistance gene Lr39 in wheat. Theoretical and Applied Genetics, 102, 347-352.

https://doi.org/10.1007/s001220051652

28. Rayburn, A.L., Gill, B.S. (1987) Molecular analysis of the D-genome of the Triticeae. Theoretical and Applied Genetics 73, 385-388. https://doi.org/10.1101/gad.260703

29. Roelfs, A.P. (1988) An International System of Nomenclature for Puccinia graminis sp. tritici. Phytopathology. https://doi.org/10.1094/phyto-78-526

30. Ruban, A.S., Badaeva, E.D. (2018) Evolution of the S-Genomes in Triticum-Aegilops Alliance: Evidences From Chromosome Analysis. Frontiers in Plant Science 9, 1756. https://doi.org/10.3389/fpls.2018.01756

31. Schneider, A., Molnár, I., Molnár-Láng, M. (2008) Utilisation of Aegilops (goatgrass) species to widen the genetic diversity of cultivated wheat. Euphytica. https://doi.org/10.1007/s10681-007-9624-y

32. Sears, E.R. (1956) The transfer of leaf-rust resistance from Aegilops umbellulata to wheat., Genetics in plant breeding. Brook-haven Symposia in Biology 1956.

33. Smit, C. (2013) Pyramiding of Novel Rust Resistance Genes in Wheat, Utilizing Marker Assisted Selection and Doubled Haploid Technology. Master's Thesis, Stellenbosch University, Stellenbosch, South Africa RSA.

34. Ulaszewski, W., Belter, J., Wiśniewska, H., Szymczak, J., Skowrońska, R., Phillips, D., Kwiatek, M. (2019) Recovery of 2R.2Sk Triticale-Aegilops kotschyi Robertsonian Chromosome Translocations. Agronomy 9, 646. https://doi.org/10.3390/agronomy9100646

35. Wang, J., Liu, Y., Su, H., Guo, X., Han, F. (2017) Centromere structure and function analysis in wheat-rye translocation lines. Plant Journal 91, 199-207. https://doi.org/10.1111/tpj.13554

\section{Figures}



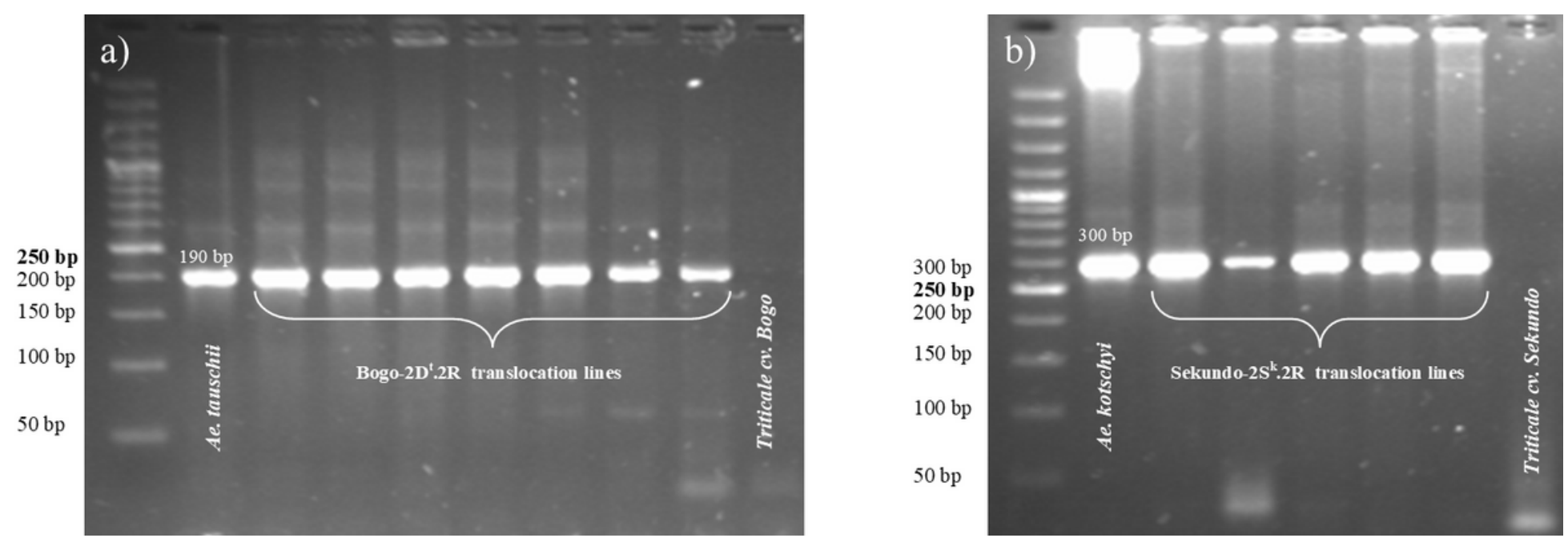

\section{Figure 1}

Amplification products of a) Xgdm35 marker linked to Lr39 leaf rust resistance gene and b) S14 marker linked to Lr54 leaf rust resistance gene. 


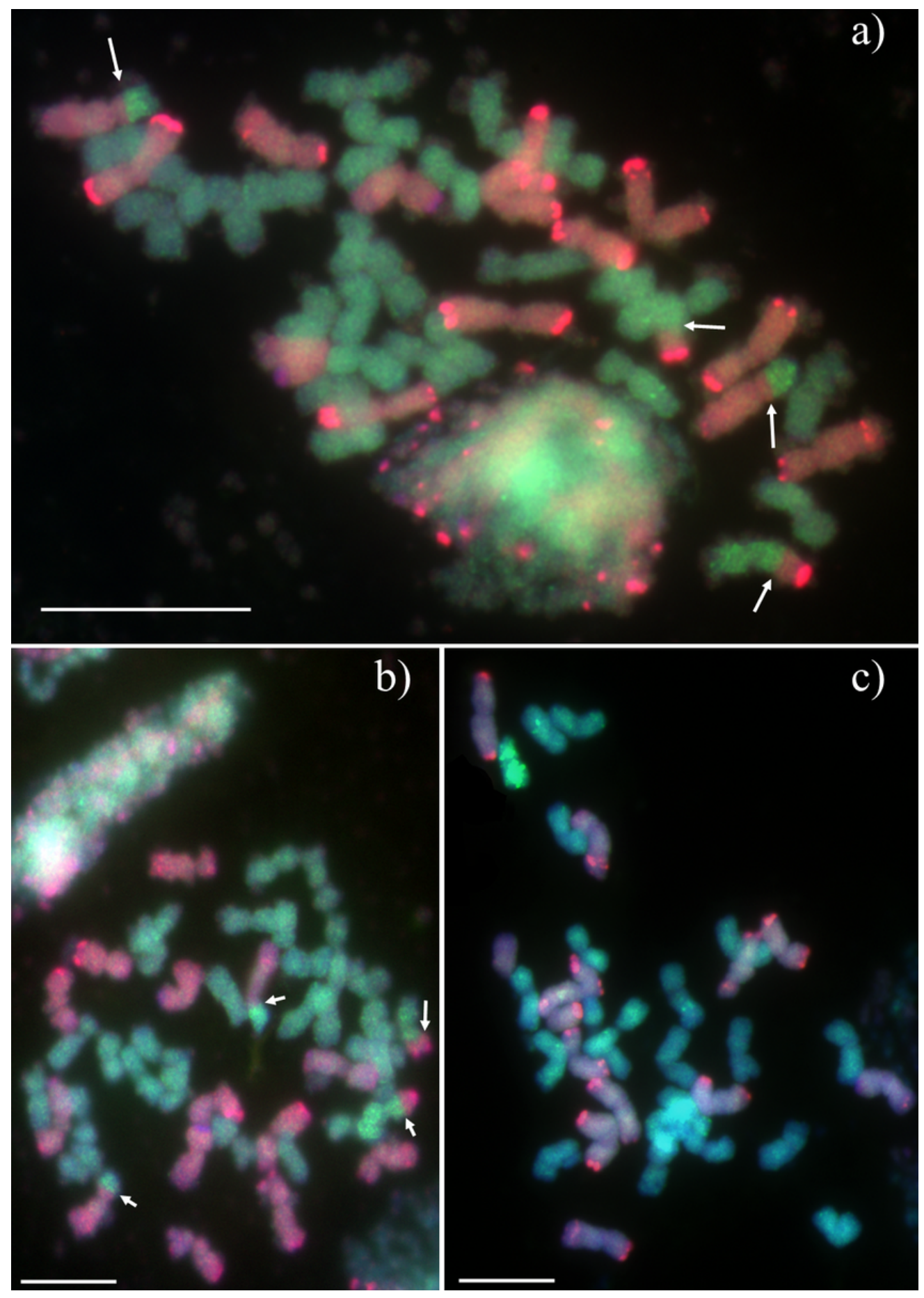

Figure 2

Karyotypes of: a) Bogo-2Dt.2R translocation plant; b) Sekundo-2Sk.2R translocation plant and c) Sekundo-2Sk/2R monosomic substitution plant examined by genomic in situ hybridization. Total genomic DNA of Aegilops tauschii (Dt-genome chromatin; green) (a) or Aegilops sharonensis (Ssh-genome chromatin; green) (b and c), rye (R-genome chromatin; red) and Triticum durum (A- and B-genome chromatin; blue) were used as probes. Arrows indicate chromosome breakpoints. Scale bar: $10 \mu \mathrm{m}$.

\section{Supplementary Files}

This is a list of supplementary files associated with this preprint. Click to download. 
- SupportingInformation1.docx

- SupportingInformation2.docx

- SupportingInformation3.docx 